Dr Radomir S. Gordić, dipl. inž.

\section{DEFINISANJE EFIKASNOSTI
ORGANIZOVANOG KOLONSKOG \\ DEFINISANJE EFIKASNOSTI SAOBRAĆAJNOG TOKA}

UDC: $355.69: 656.13$

Rezime:

U radu je prikazan pristup definisanju efikasnosti kolonskog saobraćajnog toka. Ukazano je na značaj, mogućnost $i$ neophodnost merenja efikasnosti motorizovane kolone u realizaciji zadataka saobraćajne podrške.

Ključne reči: efikasnost, kriterijum, sistem, motorizovana kolona, kretanje.

\title{
DEFINING THE EFFICIENCY OF ORGANIZED MILITARY COLUMN TRAFFIC
}

\section{Summary:}

An approach in defining the efficiency of military column traffic has been analyzed. The paper points out the importance, possibilities and the necessity to measure the efficiency of the motorized column in the task realization process.

Key words: efficiency, criteria, system, motorized column, movement.

\section{Uvod}

Za organizacione sisteme efikasnost je značajan kibernetski pojam kojem se posvećuje sve veća pažnja. Motorizovana kolona je složen organizacioni sistem kibernetskih svojstava, čijim je radom potrebno upravljati. Zbog toga se u realizaciji zadataka postavlja pitanje - da li motorizovana kolona postiže zadovoljavajuće rezultate $\mathrm{u}$ radu, $\mathrm{u}$ datim uslovima, $\mathrm{u}$ odnosu na postavljene ciljeve? U praksi se javlja i dilema kako da se meri i ocenjuje efikasnost organizovanih vojnih kolona?

Da bi odgovorili na ova pitanja potrebno je: definisati efikasnost organizovane vojne kolone, sistemski i deskriptivno je analizirati, odrediti njen sadržaj i izvršiti njenu kvantifikaciju, odrediti donji dopušteni nivo efikasnosti i intervale $u$ kojim kolona postiže zadovoljavajuće rezultate. Pored toga, potrebno je odabrati merodavne kriterijume efikasnosti i odrediti normative kretanja motorizovanih kolona. Odgovori na ova pitanja dati su u [1], a u ovom radu definisana je efikasnost kolonskog saobraćajnog toka.

$\mathrm{Na}$ ovaj način stvoreni su uslovi za vrednovanje efikasnosti kretanja organizovanih vojnih kolona i praćenje rezultata iste kolone, u različitim i različitih kolona $\mathrm{u}$ istim uslovima, što je za upravljanje kolonskim tokovima veoma značajno.

\section{Osnovni pojmovi o efikasnosti}

Bilo kakva rasprava i istraživanje efikasnosti organizovanih kolonskih saobraćajnih tokova, ${ }^{1}$ ne može se započeti

Pod pojmom „organizovan kolonski saobraćajni tok“ podrazumeva se „,vojna motorizovana kolona“, „,kolona vojnih motornih vozila“" ili samo „kolona“. 
dok se ne definiše pojam „efikasnost“ i sa tog aspekta ne da bliže teorijsko određenje pitanja: ,šta je efikasnost organizovanog kolonskog saobraćajnog toka?“

Na prvi pogled, preciznije definisanje pojma „efikasnost“ izgleda nepotrebno, jer se termin tako često koristi da je postao sastavni deo žargona i stručnog izražavanja u svim oblastima ljudske delatnosti. Upravo ta univerzalnost pojma „efikasnost" u praksi zbunjuje, usled čega dolazi do otežanog komuniciranja, upoređivanja, vrednovanja i uopšte razumevanja. Posebno smeta fluidnost granica ovog pojma, njegovo razgraničenje i nekritičko mešanje, pa i poistovećivanje sa pojmom ,efektivnost".

Tražeći kompetentan odgovor $\mathrm{u}$ raznim priručnicima i enciklopedijama, zapažamo da neka enciklopedijska izdanja kao što su: „Tehnička enciklopedija“, „Vojna enciklopedija“, „,Mala enciklopedija Prosveta“, „Vojni leksikon“" i dr. ne objašnjavaju pojam ,efektivnost". Bez obzira na ovu činjenicu, u brojnim izvorima objašnjeno je značenje pojmova „efikasnost“" i „efektivnost", pa se, pored značenja, mogu uočiti njihove međusobne veze i odnosi.

U Vujaklijinom Leksikonu stranih reči i izraza piše da je efikasnost (lat. efficacitas) ,dejstvenost, delatnost, radinost, uspešnost“ [2]; dok se pojam ,efektivnost" ne pominje.

Organizaciono-poslovni leksikon [3] odvojeno objašnjava ove pojmove, ali ih smatra sinonimima, bez obzira na različitost značenja. Tako se kaže da je efikasnost (fr. efficacite) delotvornost, podobnost da se izazove određeni učinak, određeni utisak i sl. Pored toga, efektivnost (lat. effectivus, stvaran, istinski; engl. efficiency, stepen ostvarenog efekta učinka) - $\mathrm{u}$ teoriji sistema jeste koeficijent odnosa između korisnog izlaza iz sistema i ulaza u sistem koji uslovljava taj izlaz. U tom smislu može se govoriti o efektivnosti mašine, proizvodnje, učenja, itd.

Ni Ekonomska enciklopedija [4] ne tretira pojam „efektivnost“, a ,efikasnost" deli na ekonomsku i tehnološku. Ekonomska efikasnost povezuje proizvodnju sa jedinicom troškova upotrebljenih resursa, a odnosi se na troškove i vrednosti. Ona ima svoje kriterijume koji su najčešće povezani s efikasnošću upotrebljenih proizvodnih faktora. Na primer, efikasnost sredstava se meri postizanjem što većeg učinka, odnosno veličinu učinka svodimo na jedinicu upotrebljenih sredstava. Tehnološka efikasnost meri proizvodnju po jedinici upotrebljenih faktora izraženih u njihovim fizičkim veličinama. Na primer, proizvodnja energije meri se količinom upotrebljenih resursa po jedinici proizvedene energije.

Kriterijumi ekonomske i tehnološke efikasnosti mogu se, ali ne moraju, podudarati. Mašina može proizvoditi robu koja zadovoljava tehničke, hemijske, inženjerske kriterijume, ali je ta proizvodnja ekonomski neefikasna, jer su troškovi tako visoki da ne postoji kupac koji će platiti takvu cenu koja pokriva te troškove [4].

U „Općoj enciklopediji“ [5] zapisano je da efikasan (fr. efficace), znači djelotvoran, snažan, uspješan, plodonosan, a efektivan (izvedeno od efekt) stvaran, istinski, koji je zaista ostvaren, izvršen.

Za naše razmatranje interesantna je definicija pojma „efikasnost ${ }^{\star 2}$ prof. S. Marjanovića, koji u [6] navodi: „Efikativnost."

\footnotetext{
${ }^{2}$ Profesor Marjanović takođe ne pominje pojam „efek-
} 
snost kao odnos između utrošenog (materijala, energije i vremena) i dobivenog zavisi ne samo od direktnih nego i od indirektnih, pa i kasnijih uslova“. Profesor Marjanović ovaj pojam tretira sistemski [6] i ističe da se efikasnost meri kriterijumima, koji se moraju razlikovati za radna mesta i za funkcionisanje organizacije. On smatra da podsistemi ne mogu povećavati efikasnost nezavisno od viših sistema, a i da se efikasnost organizacije ne bi trebalo povećavati nezavisno od efikasnosti podsistema, obrazlažući to činjenicom ,.. . . da su ljudi skloni da sebi olakšaju posao otežavajući ga drugima". Proučavajući efikasnost rada profesor Marjanović u [6] navodi da ona obuhvata: fiziološku, psihološku, sociološku, organizacijsku i ekonomsku efikasnost i da se njihove posledice na uspeh funkcionisanja sistema ispoljavaju istovremeno i celovito, pa je ,.. . za organizaciju u celini značajna rezultantna efikasnost" [6].

Iz izloženog se može zaključiti:

1. Uspešnost funkcionisanja složenih sistema vrednuje se sa različitih aspekata (ekonomski, tehnološki, organizacijski i dr.). Postizanje efikasnosti sa jednog ne znači efikasnost i sa drugog aspekta, radi čega su ovi pojmovi ponekad konfliktni i protivrečni.

2. Za razliku od „efektivnosti“" koja se odnosi samo na ostvareni - dostignuti učinak, ,efikasnost" obuhvata i potencijal sistema i služi za ocenu i vrednovanje njegovih mogućnosti.

3. Efikasnost je, dakle, širi pojam, koji sadrži efektivnost, koja se odnosi na ocenu ostvarenog rada-učinka-efekta, pre svega tehničkih sistema sa tehno-ekonomskog aspekta, najčešće u jedinici vremena.
4. Efikasnost se koristi kao sistemska ocena uspešnosti funkcionisanja složenih sistema, jer se prema [6], kod sistema koje karakteriše veliki broj relevantnih faktora i deterministička obeležja, optimalnost odvijanja procesa procenjuje preko kriterijuma ${ }^{3}$ efikasnosti.

5. Efikasnost nije apsolutna kategorija, ona zavisi od ciljeva sistema i menja se sa promenom „ulaza“. Važna svojstva efikasnosti su integralnost i celovitost, koja obezbeđuju ukupnu „rezultantnu“ efikasnost.

\section{Sistemski prilaz definisanju efikasnosti organizovanog kolonskog saobraćajnog toka}

Vojna motorna vozila $(\mathrm{m} / \mathrm{v})$ jesu tehnička osnovica realizacije saobraćajno-transportnih zadataka jedinica Vojske u miru i odbrani zemlje. Uspešnost vojnih motorizovanih kolona, pored tehničke osnovice zavisi od: kadrova (u kvalitativnom i kvantitativnom smislu), organizacije saobraćaja, upravljanja saobraćajem (komandovanja jedinicama i kolonama), uslova odvijanja saobraćaja, opštih mogućnosti društva i koncepcije odbrane.

Kada su u pitanju pojedinačna $\mathrm{m} / \mathrm{v}$ kao elementi naoružanja i vojne opreme (NVO), njihov uspeh u vojnom drumskom saobraćaju zavisi, pre svega, od taktičko-tehničkih osobina. Sa razvojem kibernetike i sistemskog prilaza, u svim sferama Vojske, sve više se govori o sistemima, koji na nešto složeniji način uvezuju u skladne celine pojedinačna tehnička sredstva (TS). Kada se radi o

${ }_{\text {kog rešenja. }}^{3}$ Pod kriterijumom se podrazumeva merilo kvaliteta ne- 
vojnom saobraćaju, govorimo o sistemima: vozač-vozilo-put-okolina (V-V-P$\mathrm{O})$, a ako posmatramo jedinice kao celine, sistem se dopunjuje „organizacijom“, pa imamo sisteme: vozač-vozilo-putokolina-organizacija ( $\mathrm{V}-\mathrm{V}-\mathrm{P}-\mathrm{O}-\mathrm{O})$, koji predstavljaju kolone određene organizacione strukture.

Osobine i efikasnost pojedinačnih $\mathrm{m} / \mathrm{v}$ potreban su, ali ne i dovoljan uslov za postizanje prihvatljive efikasnosti kolona $\mathrm{u}$ koje su spregnuta. Efikasnost kolone podrazumeva maksimiziranje efikasnosti pojedinačnog sistema $\mathrm{V}-\mathrm{V}-\mathrm{P}-\mathrm{O}$, ali i njegovo skladno funkcionisanje u složenom sistemu-koloni. Efikasnost kolone je višestruko veća od efikasnosti pojedinačnog sistema $\mathrm{V}-\mathrm{V}-\mathrm{P}-\mathrm{O}$, ali se ne može dobiti prostim zbirom pojedinačnih efikasnosti, zbog interakcija koje vladaju u sistemu.

Da bi dali odgovor na već postavljeno pitanje: ,šta je efikasnost organizovanog kolonskog saobraćajnog toka", moramo ostati dosledni opštem značenju pojma ,efikasnost". Opšte značenje ovog izraza predstavlja uspešnost funkcionisanja nekog sistema sa dva aspekta, kao potencijal ili mogućnost, na ulazu i kao rezultat-rešenje, na izlazu iz sistema. Ovako uopšteno shvatanje efikasnosti mora se konkretizovati da bi odgovaralo osnovnim obeležjima kolone, ali istovremeno mora biti dovoljno uopšteno da bi se moglo meriti sistemom različitih kriterijuma.

Prema tome, u ovom radu „Efikasnost organizovanog kolonskog saobraćajnog toka je mogućnost (na ulazu) i/ili sposobnost (na izlazu) njegovog funkcionisanja u oblasti dopuštenih stanja ${ }^{4}$ sistema“.

\footnotetext{
${ }^{4}$ Oblast dopuštenih stanja sistema ili oblast rešenja je oblast u kojoj sistem postiže zadovoljavajuće rezultate u radu, $\mathrm{u}$ datim uslovima, u odnosu na postavljene - usvojene ciljeve.
}

Iz ove definicije zaključujemo da je efikasnost kolonskog saobraćajnog toka, ex post kategorija, jer se o njoj može govoriti tek posle obavljenog zadatka - kretanja, odnosno pružanja saobraćajno-transportne usluge, kao o dokazanoj sposobnosti; pojedinačnog sistema $\mathrm{V}-\mathrm{V}-\mathrm{P}-\mathrm{O}$, angažovane saobraćajno-transportne strukture (kolone), ili jedinice kao celine. Sposobnost funkcionisanja - rada kolone, međutim postoji i ex ante, kao potencijal (mogućnost) realizacije saobraćajno-transportnih zadataka sa određenim stepenom uspešnosti. Tu potencijalnu, još nedokazanu, ali postojeću efikasnost (sposobnost) organizovanih kolonskih tokova, potrebno je ponekad sagledati i vrednovati pre pristupanja realnim zadacima ${ }^{5}$ saobraćajne podrške (SbPo). Na sadašnjem stepenu razvoja teorije o organizaciji vojnog drumskog saobraćaja i praktičnih rešenja u ovoj oblasti, u Vojsci Srbije je nemoguće vrednovati taj potencijal, kao i realne domete efikasnosti kolonskog toka, jer nije razrađena metodologija, niti je za to razvijen sistem merodavnih kriterijuma.

Bez obzira na to kako tretiramo efikasnost kolona, kao ex post ili ex ante kategoriju, ona je determinisana, pre svega:

- prosečnom osposobljenošću kadrova (obučenost i uvežbanost rukovodećeg kadra, vozača i saobraćajaca);

- stepenom razvoja nauke i njene tehnološke integralnosti u oblasti vojnog drumskog saobraćaja;

- sistemskim rešenjima organizacije vojnog drumskog saobraćaja (kolonskog saobraćajnog toka);

Ova potreba javlja se u proceni situacije, na osnovu koje se podnosi predlog komandantu o upotrebi jedinica i načinu realizacije zadataka. 


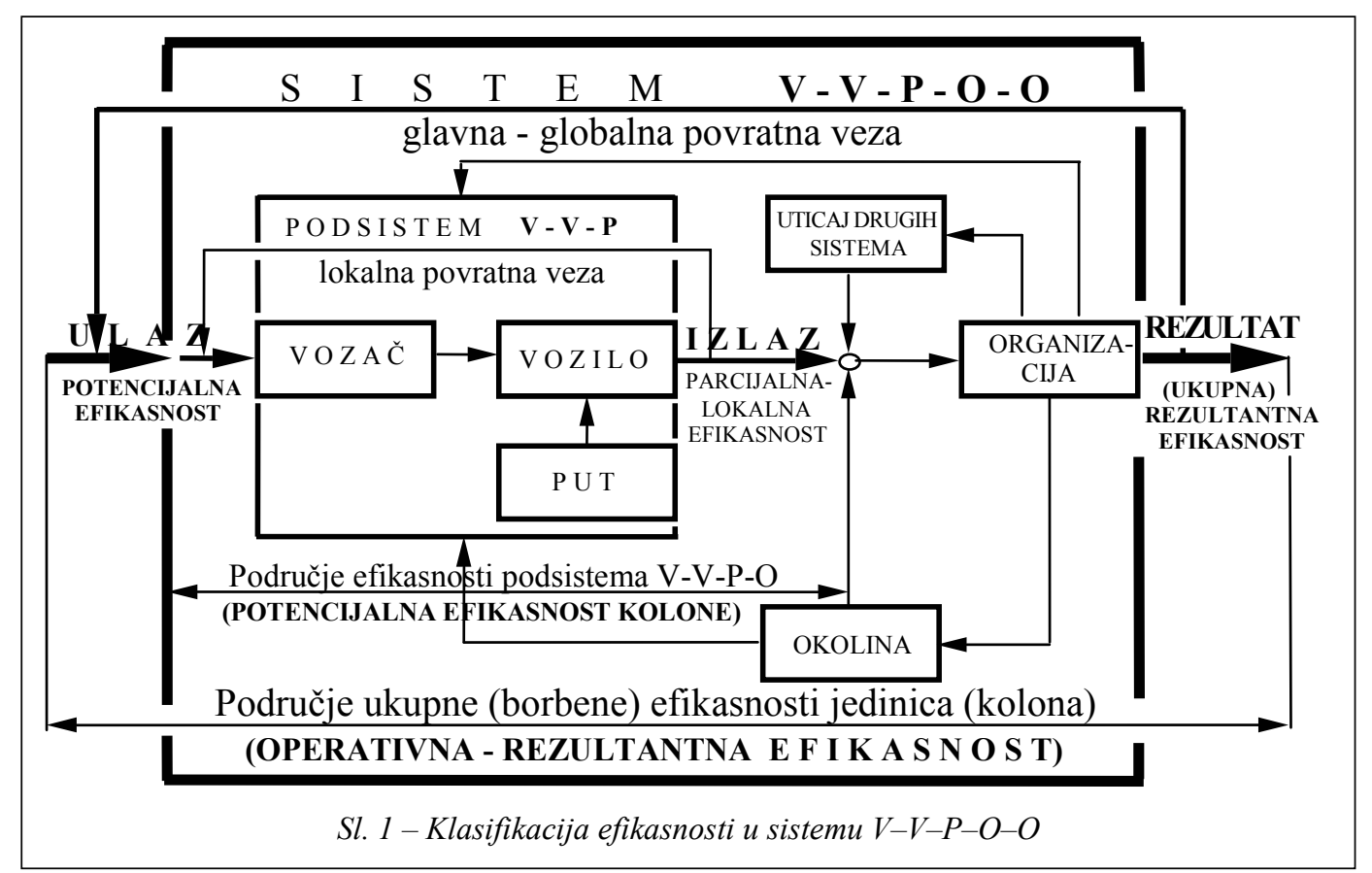

- brojem i karakteristikama $\mathrm{m} / \mathrm{v}$ i drugih TS, koja doprinose funkcionisanju kolonskih tokova, $\mathrm{i}$

- stanjem i interakcijama u sistemu $\mathrm{V}-\mathrm{V}-\mathrm{P}-\mathrm{O}-\mathrm{O}$ i sistema sa okolinom.

\section{Klasifikacija efikasnosti u sistemu $\mathrm{V}-\mathrm{V}-\mathrm{P}-\mathrm{O}-\mathrm{O}$}

Prema opštoj teoriji sistema i usvojenoj definiciji, kod sistema $\mathrm{V}-\mathrm{V}-\mathrm{P}-\mathrm{O}$, ulaz u sistem je potencijalna efikasnost, a izlaz je parcijalna - lokalna efikasnost (sl. 1). Parcijalna efikasnost sistema V$\mathrm{V}-\mathrm{P}-\mathrm{O}$ je njegova stvarna efikasnost, jer je na ovom nivou organizacije uspeh determinisan tehničkom komponentom mogućnostima vozila, stanjem i karakteristikama puta, sposobnostima vozača i uticaja okoline. Istovremeno, to je potencijalna efikasnost kolone.
U žiži interesovanja Vojske, sa aspekta uspešnosti jedinica u borbenim dejstvima (b/d), najvažniji je ishod oružane borbe. Takva efikasnost jedinica Vojske poznata je pod nazivom „borbena efikasnost" [7], ako se odnosi na borbene sisteme i elemente NVO. Ona služi kao mera uspeha $\mathrm{u} b / \mathrm{d} u$ odnosu na postavljene ciljeve. I kod saobraćajno-transportnog sistema možemo usvojiti istu terminologiju, jer se kretanje jedinica i kolona smatra borbenom taktičkom radnjom, ${ }^{6}$ ali je zbog karaktera zadataka koje izvršavaju vojne motorizovane kolone i automobilske jedinice (atj) u b/d, povoljnije uvesti pojam „operativna efikasnost“" ${ }^{7}$ jer se ona funkcionalno odnosi na operativne zadatke.

\footnotetext{
${ }^{6}$ Prema Pravilu divizija kopnene vojske, SSNO, IV uprava, GŠ JNA, Beograd, 1979.

${ }^{7}$ Ovaj pojam odnosi se na operativne planove i zadatke, a ne na operativne jedinice.
} 
U praksi se nameće pitanje: „Ko je nosilac borbene, odnosno operativne efikasnosti sistema $\mathrm{V}-\mathrm{V}-\mathrm{P}-\mathrm{O}-\mathrm{O}$ “? U nekim radovima [7] i delu vojnostručne javnosti smatra se da su to sredstva NVO, pa se govori o „borbenoj efikasnosti sredstava NVO“, što je prema usvojenoj definiciji i sl. 1, sa aspekta sistema $\mathrm{V}-\mathrm{V}-\mathrm{P}-\mathrm{O}-\mathrm{O}$ pogrešno. Motorna vozila, kao elementi NVO, mogu svojim osobinama bitno predodređivati borbenu-operativnu efikasnost, ali je nikako sama po sebi, ne mogu obezbediti, jer na to utiču i drugi elementi podsistemi, kao što su: „vozač“", „put", „organizacija“, „okolina“" i ,drugi sistemi“" (sl. 1). Područje definicije efikasnosti podsistema $\mathrm{V}-\mathrm{V}-\mathrm{P}-\mathrm{O}$ proteže se od potencijalne do parcijalne lokalne efikasnosti kao „potencijalna efikasnost kolone", koja kao jedan od determinirajućih elemenata učestvuje u formiranju ukupne (borbene) efikasnosti atj (kolona), što predstavlja „operativnu-rezultantnu efikasnost". Područje ukupne (borbene) efikasnosti atj (kolona), ili sistema $\mathrm{V}-\mathrm{V}-\mathrm{P}-\mathrm{O}-\mathrm{O}$ (sl. 1), proteže se od potencijalne efikasnosti do rezultata postignutih u realizaciji zadataka SbPo, najčešće združeno-taktičkih jedinica (ZTJ), kao rezultantna efikasnost i učestvuje u izgradnji njihove borbene efikasnosti.

\section{Struktura efikasnosti organizovanog kolonskog saobraćajnog toka}

U nastojanju za postizanjem zadovoljavajuće efikasnosti organizovanih vojnih kolonskih tokova postoje dva shvatanja. Po jednom, nemoguće je očekivati respektivnu efikasnost kolona - jedinica $u \mathrm{~b} / \mathrm{d}$ bez zadovoljavajuće tehničke efikasnosti $\mathrm{m} / \mathrm{v}$ i drugih TS. Po dru- gom shvatanju, i uz najbolju tehničku efikasnost može izostati borbena efikasnost jedinica, ako i ostali elementi u strukturi Vojske nisu skladno uklopljeni i ravnomerno razvijani. Drugo shvatanje odnosi se na ljudski faktor u oružanoj borbi i to na njegovu motivaciju, obučenost, uvežbanost i umešnost u rukovođenju i komandovanju (upravljanju) kolonama i jedinicama. Po ovom pitanju naša doktrinarna opredeljenja su jasna i pravilno tretiraju sve faktore oružane borbe, ali u praksi ima određenih problema.

Kada je u pitanju sistem $\mathrm{V}-\mathrm{V}-\mathrm{P}-\mathrm{O}-$ $\mathrm{O}$, svi njegovi elementi nisu skladno razvijani, pa je u određenim fazama razvoja saobraćajnog sistema dolazilo do značajnijih problema u njegovom funkcionisanju, sa nekih aspekata. ${ }^{8}$ Podsistemi ,vozač“" i ,put", nisu adekvatno pratili razvoj podsistema „Vozilo“, a podsistem „organizacija“ u vojnom drumskom saobraćaju još uvek je nedovoljno istražen, a rešenja do kojih se u brojnim radovima došlo limitirana su u primeni kadrovskim ograničenjima.

Organizovanim vojnim kolonama kao sistemima nedostaje podsistem ,veze“, pa je upravljanje njihovim radom otežano ili skoro nemoguće, posebno u vanrednim uslovima i odbrani. Pošto one zadatke izvršavaju u celoj zoni odgovornosti ZTJ, pa i operativno-strategijskih grupacija i to u kretanju, to problem čini složenijim. Ovaj podsistem ni strukturno ni funkcionalno nije ugrađen $\mathrm{u}$ vojne kolonske tokove, a od njega će u određenim uslovima odlučujuće zavisiti njihova efikasnost.

${ }^{8}$ Kod nas je bezbednost u saobraćaju, i zbog ovih razloga, na znatno nižem nivou nego u razvijenim zemljama. 


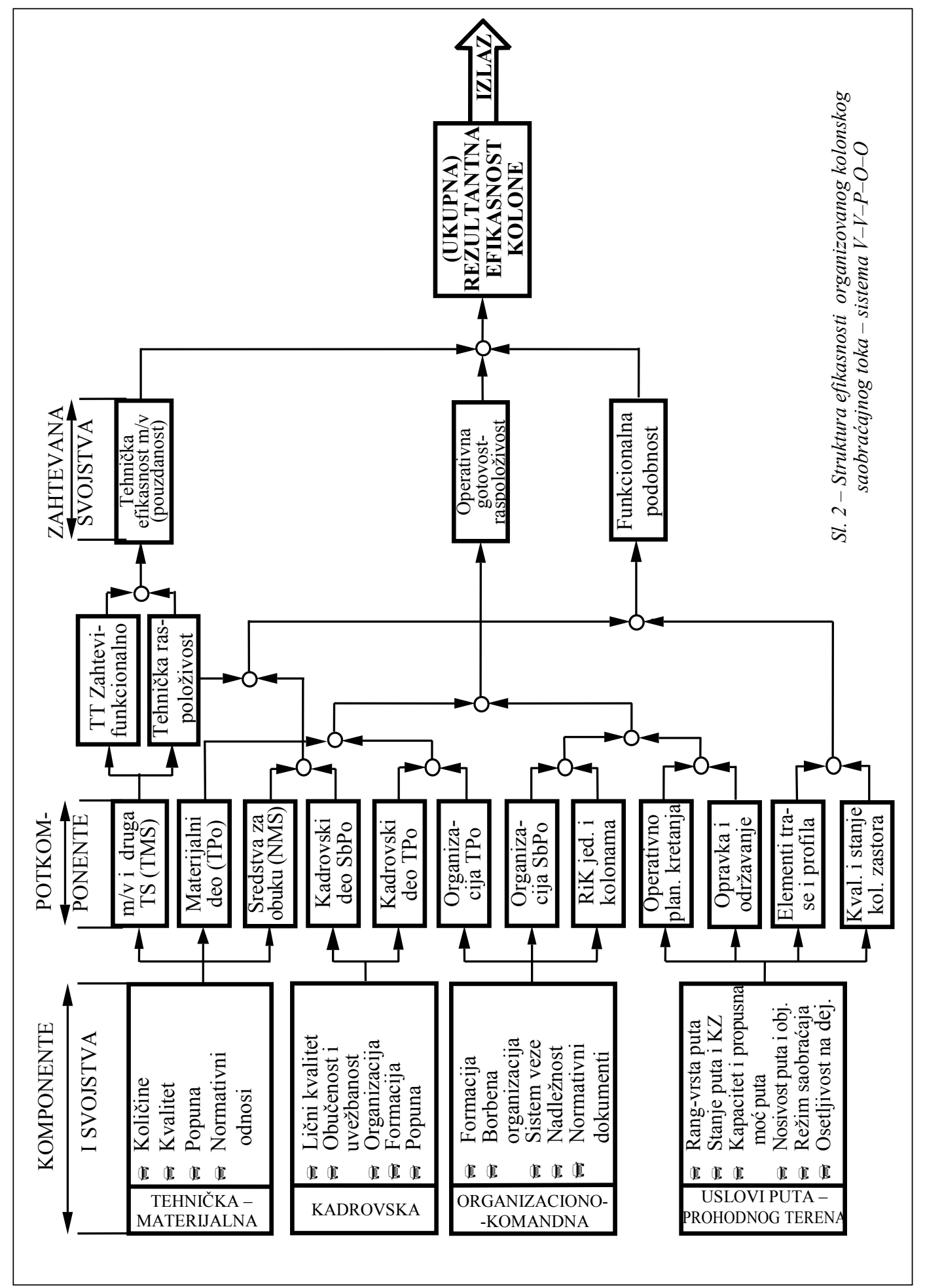


$\mathrm{Na}$ sl. 2. prikazana je struktura ukupne - rezultantne efikasnosti organizovanog kolonskog toka. Prema teorijskim saznanjima u formiranju rezultantne efikasnosti kolona - jedinica učestvuju četiri komponente: tehničko-materijalna, kadrovska, organizaciono-komandna i uslovi odvijanja saobraćaja (uslovi puta i prohodnog terena). Podele i nazivi ovih komponenti mogu biti i drugačiji, ali su njihovi sadržaji i svojstva uvek isti.

Materijalna komponenta obuhvata tri potkomponente: $\mathrm{m} / \mathrm{v}$ i druga $\mathrm{TS}$, sredstva za obuku (nastavna materijalna sredstva - NMS) i materijalni deo tehničke podrške (TPo) organizovanih kolona (sl. 2). Od tehničke efikasnosti m/v, kao tehničkog podsistema u složenom sistemu kolona, odlučujuće zavisi ukupna operativna efikasnost. Tehnička efikasnost $\mathrm{m} / \mathrm{v}$, kao mera kvaliteta njihove uspešnosti jednoznačno je merljiva, ${ }^{9}$ kao i sve tehnički egzaktno definisane kategorije. Međutim, u praksi se javlja dilema kako da se meri i ocenjuje tehnička efikasnost $\mathrm{m} / \mathrm{v}$ ? Na prvi pogled, problem se svodi na „ocenu ispunjenja taktičko-tehničkih zahteva“" (TTZ), jer od njih zavisi učinak $\mathrm{m} / \mathrm{v}$. Ispunjenje TTZ je jedan od važnih elemenata njihove efikasnosti, ali postoji i drugi, a to je njihova ,tehnička raspoloživost" korisnicima i nominalnoj nameni. Prema tome, analogno sredstvima NVO [7], tehnička efikasnost $\mathrm{m} / \mathrm{v}$ ima dve komponente, od kojih je prva ispunjenje TTZ ili „funkcionalnost“" taktičke prirode, a druga „tehnička raspoloživost" isključivo materijalno-tehničke prirode iz

${ }^{9}$ Tehnička efikasnost podsistema ,vozilo“ neće se u ovom
radu posebno analizirati ni meriti po njenim komponentama. Ona se posmatra integralno u okviru efikasnosti višeg sistema. oblasti TPo. Tehnička raspoloživost, kao numerički kvantifikator, može se analitički posmatrati, ali to vodi u oblast efektivnosti.

Kadrovska komponenta obuhvata dve potkomponente; kadrovski deo SbPo (vozači, saobraćajci, rukovaoci i komandni kadar SbSl) i kadrovski deo TPo, koje zajedno i ravnopravno utiču na operativnu efikasnost organizovanih vojnih kolona. Na ovu komponentu posebno se može uticati kroz obuku i izbor kadrova, na čemu se posebno insistira u ruskoj literaturi.

Organizaciono-komandna komponenta sadrži tri potkomponente: organizaciju SbPo, organizaciju TPo i RiK jedinicama i kolonama (sl. 2). Značaj i uloga ove komponente, u dosadašnjem radu neopravdano je potcenjivan i zanemarivan, jer se preko njenih svojstava i sadržaja dominantno može uticati na efikasnost kolona. Ova komponenta obuhvata funkciju upravljanja, koja se ostvaruje preko potkomponente RiK jedinicama i kolonama. Zbog toga je značajno da svi podsistemi, preko kojih se ostvaruje upravljanje kolonom, ${ }^{10}$ budu razvijeni i skladno uklopljeni u ovu komponentu. Dosadašnja istraživanja [8] pokazala su da su neki podsistemi, a posebno podsistem ,veze“, nedovoljno zastupljeni u upravljanju kolonama, jer nedostaje struktura, uređaji i oprema, a ni funkcije nisu razrađene. Potkomponenta RiK, a time i funkcija upravljanja, ne mogu se ostvariti ako je podsistem „veze“ nerazvijen. Zbog toga se, u toku realizacije zadatka na efikasnost ne može uticati, ona

\footnotetext{
${ }^{10}$ Pod ovim se podrazumeva upravljanje kretanjem kolone.
} 
se ne može pravilno vrednovati, a ni ostvariti u potencijalnim granicama.

Uslove odvijanja saobraćaja (uslove puta) sačinjavaju potkomponente: operativno planiranje kretanja, opravka i održavanje puteva i objekata infrastrukture, elementi trase i profila puta, kvalitet i stanje kolovoznog zastora.

Funkcionalnom kombinacijom ovih potkomponenti (sl. 2) dobija se struktura zahtevanih svojstava, koja obuhvataju: tehničku efikasnost $\mathrm{m} / \mathrm{v}$ - pouzdanost, operativnu gotovost - raspoloživost i funkcionalnu podobnost, koje zajedno daju ukupnu - rezultantnu efikasnost ${ }^{11}$ kolonskih tokova. Pošto je srednje vreme između otkaza celina koja objedinjava kvalitet i pouzdanost $\mathrm{m} / \mathrm{v}$ (TS), to se $\mathrm{u}$ nekim izvorima [9] navodi da efikasnost - efektivnost obuhvata: pouzdanost, operativnu gotovost $\mathrm{i}$ funkcionalnu podobnost.

Za razliku od egzaktno merljivog parametra tehničke raspoloživosti, ostali su nemerljivi i spadaju u tzv. kvalitativne parametre. Radi toga se efikasnost sistema $\mathrm{V}-\mathrm{V}-\mathrm{P}-\mathrm{O}-\mathrm{O}$ ne može dobiti analitički, prostim vezama elemenata i njihovih svojstava. Ona se najpovoljnije može izraziti modeliranjem kolonskih saobraćajnih tokova, jer se tako u nju uključuju interakcije između elemenata sistema i sistema sa okolinom.

Imajući u vidu strukturu efikasnosti (sl. 2), može se zaključiti da efikasnost kolona u realizaciji zadataka SbPo mnogo više zavisi od veštine (obučenosti) za upravljanje $\mathrm{m} / \mathrm{v}$, organizacije kolonskih

\footnotetext{
U nekim izvorima [9] preko ovih svojstava izražava se „efektivnost“" sistema, kao „,verovatnoća da će sistem u određenom vremenu biti u radu“, pa se ova svojstva smatraju komponentama efektivnosti.
}

saobraćajnih tokova, veštine i organizacije upravljanja njihovim radom. Naime, tehnička efikasnost u sistemu V-V-P$\mathrm{O}-\mathrm{O}$ može se smatrati konstantom, pošto se na nju, posle ispunjenja TTZ, gotovo ne može uticati. Jedini način povećanja ukupne-rezultantne efikasnosti je: umešno upravljanje $\mathrm{m} / \mathrm{v}$, umešno RiK, pravilna organizacija kolona i upravljanja njihovim radom.

\section{Kvantifikacija efikasnosti kretanja kolone}

Za upravljanje organizacionim sistemima efikasnost je vrlo značajna, pa joj se u novije vreme posvećuje veća pažnja. Postoji više definicija ovog pojma, koje se razlikuju i više pokušaja da se on konkretizuje i odredi prema interesima i ciljevima sistema na koji se odnosi. Tako se, prema [10], efikasnost definiše kao određeni nivo uspešnog poslovanja nekog dela radne organizacije (RO) ili RO u celini, odnosno grane industrije, pri čemu rezultat efikasnosti poslovanja proizilazi iz analize o ekonomičnosti, produktivnosti, rentabilnosti i racionalnosti.

Polazeći od definicije usvojene $u$ ovom radu, efikasnost kretanja kolone može se iskazati odnosom između određene ostvarene merljive koristi i troškova (resursa) koji su nastali (angažovani) ostvarivanjem te koristi.

Problem merenja i izražavanja efikasnosti bilo kog sistema - organizacije oduvek je bio interesantan, za praktičare i teoretičare. Koncepcija merenja efikasnosti svodi se na razmatranje organizacija kao proizvodnih sistema, koji transformišu višestruke ulaze (resurse) u vi- 
šestruke izlaze (robu i usluge) kroz organizaciju, upravljanje i tehnologiju. U ovom radu razmatra se merenje efikasnosti organizovanog kolonskog saobraćajnog toka, kao složenog organizacionog sistema koji se ne rukovodi profitom. Efikasnost se odnosi na kretanje i svodi na uspešnost realizacije zadataka kolone, odnosno kolonskog saobraćajnog toka. To je sistemska mera (ocena) uspešnosti funkcionisanja kolone sa aspekta organizacije, iskorišćenja (resursa) puta, vremena, brzine, konfora i dr.

U prirodnim naukama i inžinjerstvu često se koriste dva različita pristupa pri merenju efikasnosti. Prvi se zasniva na upoređivanju ostvarenog izlaza sa standardnim ili unapred određenim izlazom, prema izrazu:

$$
\text { EFIKASNOST }=\frac{\check{c} \text { ist izlaz }}{\text { standardni izlaz }}
$$

S obzirom na to da standardni izlaz predstavlja maksimalno mogući izlaz za date uslove, efikasnost definisana na ovaj način ima vrednost između 0 i 1.

Ovakav pristup nije uvek primenjiv, pogotovu ne u vojnim sistemima. Kada bi, na primer, bilo moguće odrediti jedan izlaz, poput maksimalnog broja vozila koja u jedinici vremena mogu proći kroz poprečni presek puta (određenu tačku) ili deonicu puta za date uslove sistema $\mathrm{i}$ okoline, tada bi efikasnost kolone mogla biti određena upoređivanjem stvarnog broja vozila koja su prošla kroz presek (deonicu) puta (opslužena vozila), sa unapred određenim maksimalnim brojem (vozila koja zahtevaju opslugu). Međutim, do sada nije razrađena metodologija kojom bi se odredio maksimalno mogući broj vozila koja mogu savladati određeni presek (deonicu) puta za mnoštvo kombinacija stanja sistema i uslova okoline. Znači, ne postoji mogućnost da se za takve situacije odrede standardi koji bi se koristili kao apsolutna mera funkcionisanja kolone. Zbog toga se sistemi koji se ne rukovode profitom, a samim tim i sistemi SbPo, moraju osloniti na relativne mere efikasnosti, koje se zasnivaju na upoređivanju empirijskih vrednosti ulaza i izlaza.

Drugi pristup odnosi se na slučajeve gde se jedan ulaz koristi za ostvarivanje jednog izlaza. U tom slučaju efikasnost se može meriti upoređivanjem ostvarenog izlaza sa ulazom koji je korišćen za ostvarivanje tog izlaza, prema izrazu:

$$
\text { EFIKASNOST }=\frac{\text { čist izlaz }}{\text { ukupan ulaz }}
$$

Prema zakonu o očuvanju energije, izlaz (proizvedena energija - broj opsluženih vozila) ne može biti veći od ulaza (utrošene energije - broja vozila koja zahtevaju opslugu) za date uslove, pa ovako definisana efikasnost poprima vrednosti između 0 i 1 . Zbog toga je, radi lakšeg razumevanja, efikasnost pogodno izražavati u procentima pa izraz (2) ima oblik:

$$
\text { EFIKASNOST }=\frac{\text { čist izlaz }}{\text { ukupan ulaz }} \cdot 100 \quad[\%]
$$

Ovakav pristup ima ograničenu primenu pri ocenjivanju efikasnosti organizacionih sistema, jer su za njihovo funk- 
cionisanje karakteristični višestruki ulazi za ostvarivanje višestrukih izlaza. Zbog toga je, da bi se mogla meriti efikasnost organizovane vojne kolone, neophodno povezati korišćene višestruke ulaze sa proizvedenim višestrukim izlazima. Ovakav pristup omogućio je pogodnu analizu efikasnosti realnog kolonskog toka automobilskih jedinica, prema različitim kriterijumima [1].

\section{Kriterijumi efikasnosti kretanja organizovanih kolona}

$\mathrm{U}$ [1] (tačka I 1) istaknuto je da kriterijumi efikasnosti organizovanih kolona nisu razrađeni, a iz $[11,12]$ može se zaključiti da se za kriterijume u vojnom saobraćaju ponekad uzimaju pogrešne ili neodgovarajuće veličine i kategorije. Miladinović u [11] ističe ovaj problem s namerom da se pokrene stručna rasprava o ovim pitanjima. On navodi da se kao pokazatelj borbene mogućnosti ${ }^{12}$ jedinica koristi ,pokretljivost jedinica“, pri čemu se ona izražava postotkom opremljenosti savremenim motornim vozilima (vozila visoke prohodnosti, nosivosti 0,$75 ; 1,5$; 3 ; 6 i 9 [t] i vozila specijalne nadgradnje), u odnosu na formaciju.

Ovaj pokazatelj ne predstavlja ,pokretljivost jedinica“, jer je to mnogo širi i složeniji pojam, već samo ukazuje na procenat popunjenosti $\mathrm{m} / \mathrm{v}$ iz fonda Vojske (FV), kao materijalnu osnovu za kretanje jedinice. On ne poseduje osnovna obeležja kriterijuma, pa je propao pokušaj da se koristi kao pokazatelj efikasnosti. Slično je i sa pokušajem da se SbPo ocenjuje taktičkim kriterijumima preko

\footnotetext{
${ }^{12}$ Borbena mogućnost predstavlja sposobnost jedinice za izvršenje zadatka u svim uslovima vođenja borbe.
}

parametra „pokretljivost“", što je objašnjeno u [1] (str. 74-86, tačka 3.3).

Kriterijumi efikasnosti organizovanih vojnih kolona mogu se posmatrati sa aspekta transportno-manipulativnih operacija ${ }^{13}$ i sa aspekta kretanja.

Za kriterijum efikasnosti kretanja organizovane kolone neophodno je usvojiti pokazatelj koji će se menjati sa promenom osnovnih parametara kolonskog saobraćajnog toka. Za kvantitativni izbor rešenja najvažnije je pravilno izabrati pokazatelj za ocenu efikasnosti - kriterijum rešenja. Za svaki kriterijum efikasnosti utvrđuje se njegova funkcionalna, odnosno matematička veza prema osnovnim parametrima operacije, pa se određuju posebne vrednosti tih parametara koje maksimiziraju ili minimiziraju vrednost usvojenog kriterijuma. Dobijene vrednosti kriterijuma su brojevi koji u određenom smislu predstavljaju očekivani ili ostvareni uspeh ${ }^{14}$ motorizovane kolone $\mathrm{u}$ kretanju.

Kriterijumi i normativi efikasnosti, sa aspekta kretanja, nisu isti za sve nivoe odlučivanja. Oni se, u principu, razlikuju za više i niže sisteme (sisteme i njihove elemente), jer su vezani za ciljeve. Prema tome, kriterijumi imaju odgovarajuću strukturu (drvo kriterijuma) i moraju biti usklađeni sa strukturom ciljeva. Ako se imaju u vidu ciljevi formiranja organizovanih kolona [1] (str. 54, sl. 3.1) i ciljevi upravljanja njihovim radom, kriterijumi efikasnosti kolona, po nivoima upravljanja, prikazani su u [1] (str. 35, tabela 2.1).

Pojedini kriterijumi po sadržaju mogu biti definisani na isti način za više ni-

\footnotetext{
${ }_{14}^{13}$ Ovi kriterijumi nisu predmet rada, pa se ne razrađuju. ${ }^{14}$ U proceni je očekivani ,ex ante“, a u analizi ostvareni „ex post“ uspeh.
} 
voa, ali im se menjaju strukture (stepen detaljisanja, metode ostvarenja, pa i vrednosti parametara). Ako se posmatra kolona kao sistem, ove karakteristike važe za obučenost vozača, vreme kretanja (vreme realizacije zadatka), brzinu kretanja i protok (propusna moć), jer su to univerzalna merila uspešnosti na svim nivoima upravljanja.

Kriterijumi efikasnosti u ratu treba da doprinesu ispunjenju cilja, tj. formiranju sistema - zadovoljenje transportnih potreba jedinica Vojske, privrede i stanovništva [1] (str. 54, sl. 3.1). Oni mogu biti kvalitativni i kvantitativni pokazatelji rada.

Kvalitativni kriterijumi efikasnosti kolone vezani su za nemerljive ili teško merljive parametre, koji po značaju mogu biti među osnovnim. U kvalitativne kriterijume spadaju:

- zahtevi doktrine odbrane prema saobraćajno-transportnom sistemu u ratnim uslovima,

- osposobljenost upravnih organa da planiraju kretanje i da u planiranju uzmu u obzir sve interakcije koje se javljaju u sistemu,

- osposobljenosti izvršnih organa (vozača i starešina u koloni) da pravilno upravljaju kolonskim tokom i da se kreću u skladu sa usvojenim planom,

- način izrade planova i pogodnost metodologije da u planiranju uzme u obzir uticaj interakcija i drugih faktora na kretanje $\mathrm{i}$

- usklađivanje konfliktnih ciljeva (realizacija zadataka za što kraće vreme, uz minimalan broj ometanja kolone i maksimalnu bezbednost), itd.

Kvantitativni kriterijumi su merljivi pokazatelji, koji se izražavaju brojčanim veličinama i fizičkim jedinicama. Ovim kriterijumima može se egzaktno oceniti i izraziti efikasnost kolonskog saobraćajnog toka.

Kriterijumi efikasnosti organizovanih kolona povezani su sa ciljevima upravljanja kretanjem kolona i predstavljaju kriterijume kvaliteta upravljanja. Razvijeni su iz strukture ciljeva upravljanja kretanjem, u [1] (str. 33-37, tačka 1.4, a prikazani su u tabeli 2.1).

Imajući u vidu ciljeve i kriterijume kvaliteta upravljanja kretanjem kolona [1] (str. 35, tabela 2.1), merodavni kvantitativni kriterijumi ${ }^{15}$ efikasnosti kretanja su: vreme putovanja (kretanja); brzina kretanja; vreme opsluživanja kolone (vreme kretanja na putu jednakom dubini kolone); broj ometanih vozila; vreme čekanja SMO - puta (gubici kapaciteta puta) i iskorišćenje propusne moći puta.

Navedeni kriterijumi i njihovi normativi određeni su u istraživanju [1] (str. 168-213, tačka 3), kao pretpostavka realnog planiranja i kontrole uspešnosti kretanja organizovanih vojnih kolona, što znači upravljanja kretanjem kolona.

\section{Upravljanje i efikasnost organizovanog kolonskog toka}

Funkcionisanje i efikasnost svakog sistema, pa i organizovane kolone, zavise od upravljanja. Funkcionisanja nema bez upravljanja, što znači da se svakim sistemom u toku rada mora upravljati. Za funkcionisanje bilo kog sistema značajan je odnos upravljanja i efikasnosti. Polazeći od definicija ovih pojmova može se zaključiti da je efikasnost širi pojam od

${ }^{5}$ Pored kvantitativnih, u tabeli 2.1. [1] prikazani su kvalitativni kriterijumi: „obučenost vozača $\mathrm{m} / \mathrm{v}$ “ $\mathrm{i}$, ,planiranje kretanja“". 
upravljanja. To je univerzalna kategorija koja se odnosi na sve sisteme, sve funkcije sistema i sve procese. U tom smislu može se govoriti i o efikasnosti upravljanja, bilo da se ono shvata kao funkcija rukovođenja ili kao proces kojim se funkcija realizuje.

Upravljanje organizovanom kolonom odvija se realizacijom funkcija upravljanja [1] (tačka II 1.2), kroz međusobno povezane i uslovljene procese, čiji je rezultat jedinstveno funkcionisanje sistema u skladu sa postavljenim ciljem. Upravljanje deluje na sistem u celini ili na njegove podsisteme. Zavisno od složenosti sistema i specifičnosti njegovih funkcija ono može imati poseban značaj za pojedine podsisteme ili funkcije. Da bi sistem mogao da ostvari postavljene ciljeve i da radi efikasno, upravljanje treba optimizirati, odnosno obezbediti njegovu efikasnost. Cilj optimizacije upravljanja je povećanje efikasnosti upravljanog sistema. Zbog toga se efikasnost smatra posledicom upravljanja. Optimizacija upravljanja odvija se, uglavnom, kroz primenu savremenih naučnih metoda $\mathrm{i}$ savremenih tehničkih sredstava. Ako su optimizacijom obuhvaćene sve funkcije upravljanja $^{16}$ [1] (tačka II 1.2), povećava se rezultantna (ukupna) efikasnost (sl. 1. i 2). Ako se optimizacija izvodi parcijalno, po funkcijama, efikasnost se povećava lokalno, povećanjem efikasnosti komponenti ili potkomponenti (sl. 1. i 2), odnosno funkcija i podfunkcija. Prema tome, unapređenjem upravljanja poboljšava se efikasnost organizovane kolone.

\footnotetext{
${ }^{16}$ Od većeg broja šema, za kolonu je najprihvatljivija struktura upravljanja koju čine funkcije: planiranje, organizovanje, izbor i raspored kadrova (vozača i starešina), koordinaci-
} ja i kontrola [1] (str. 29).
Organizovana kolona je dinamički sistem, kod kojeg je izvršna funkcija kretanje [1] (sl. 2.1, str. 25), najznačajnija za njegovo funkcionisanje. Efikasnost kolone ostvaruje se preko ove funkcije. Zbog toga, upravljanju kretanjem organizovane kolone treba posvetiti posebnu pažnju. Organizovanom kolonom se zbog dinamičkih svojstava ${ }^{17}$ mora upravljati u realnom vremenu. Ovaj problem u našoj vojsci do sada nije rešen, jer primenjene metode i sredstva ne omogućavaju upravljanje u realnom vremenu.

Povećanje, odnosno poboljšanje efikasnosti organizovane vojne kolone i optimizacija upravljanja kretanjem mogu se postići primenom dva parcijalna modela upravljanja: izborom optimalnog puta za kretanje kolone i upravljanjem kretanja kolone sistemom za globalno pozicioniranje - GPS-om.

Ovi modeli razrađeni su i objašnjeni u [1] (str. 216-247).

Pri izboru optimalnog puta za kretanje treba voditi računa o specifičnostima kolone i uzeti u obzir interakcije između elemenata sistema (elementi podsistema $\mathrm{V}-\mathrm{V}-\mathrm{P}-\mathrm{O}$, podsistemi $\mathrm{V}-\mathrm{V}-\mathrm{P}-\mathrm{O}$ i formacije u koloni) i sistema sa okolinom.

Za primenu modela upravljanja kretanjem kolone GPS sistemom potrebno je:

- obezbediti funkcionisanje mobilnih veza u koloni i kolone sa centrom upravljanja;

- izvršiti izbor sistema i konkretnog GPS uređaja - prijemnika;

- opremiti jedinice sistemom za globalno pozicioniranje - GPS, i

${ }^{17}$ Pod ovim se podrazumeva svaka promena stanja sistema, a ne samo kretanje u fizičkom smislu. 
- uspostaviti organizaciju upravljanja kretanjem kolona primenom ovog sistema.

Primena GPS obezbedila bi upravljanje kretanjem i sveobuhvatno praćenje parametara kolonskog saobraćajnog toka u realnom vremenu.

\section{Zaključak}

Efikasnost organizovanog vojnog kolonskog saobraćajnog toka je složen operativno-tehnički pokazatelj uspešnosti funkcionisanja organizovanih vojnih kolona. Ovaj pokazatelj nije definisan i teorijski izučen, pa su mu, pored nepoznatog terminološkog određenja pojma, nejasni i sadržaj, struktura, parametri i kriterijumi pomoću kojih se izražava i vrednuje.

Složena struktura i uslovi rada, uticaj okoline i delovanje ograničenja zahtevaju permanentno istraživanje, praćenje i vrednovanje efikasnosti organizovanih kolonskih tokova, da bi se moglo uspešno upravljati njihovim radom.

Osnovno pitanje efikasnosti organizovanog vojnog kolonskog saobraćajnog toka je: šta je „efikasnost“, koji je njen donji dopušteni nivo i kako ga odrediti? Odgovor na ovo pitanje dat je u radu, a u [1] je kreiranim modelima celishodno i sveobuhvatno razrađen i konkretizovan, prema uvedenim kriterijumima.

Prema izloženom, efikasnost organizovanog kolonskog saobraćajnog toka može se uspešno meriti upoređivanjem ostvarenog izlaza (merljive koristi) sa ulazom, koji je korišćen za ostvarivanje tog izlaza (angažovani resursi).
Nedostatak kriterijuma u pogodnom obliku za praktičnu primenu odražava se na funkcionisanje saobraćajno-transportne strukture i upravljanje njenim radom u svim fazama realizacije zadataka SbPo. Zbog nedostatka kriterijuma, nerealna je procena mogućnosti jedinica i kolona, pa je radi toga i planiranje nerealno, jer planovi ne sadrže interakcije između pojedinih elemenata sistema i uticaje koji se generišu u sistemu i okruženju. Radi toga se planovi u praksi teško ostvaruju, pa se u narednim fazama rukovođenja upravljanje vojnim saobraćajem suštinski ne ostvaruje. U takvoj situaciji saobraćajno-transportna struktura često deluje u oblasti nedopuštenih stanja, što znatno umanjuje njenu efikasnost, a upravljanje ne daje željene efekte, jer se korektivnim merama i akcijama sistem ne može vratiti u oblast dopuštenih stanja.

Efikasnost organizovanog vojnog kolonskog saobraćajnog toka posledica je upravljanja njegovim funkcionisanjem, koje se, u osnovi, svodi na kretanje. Kretanje (realizacija, funkcionisanje) jeste specifična i jedino produktivna funkcija kolone. Od nje zavisi i preko nje se procenjuje efikasnost funkcionisanja kolone. Zbog specifičnosti ove funkcije i problema koji se generišu u toku kretanja, nameće se potreba upravljanja radom kolone u realnom vremenu, dakle, tokom kretanja.

U postojećoj organizaciji vojnog saobraćaja ne postoje uslovi za celishodno upravljanje kolonom u toku kretanja (u realnom vremenu), jer nije uspostavljen i ne funkcioniše sistem mobilnih veza, pa se ne mogu obezbediti informacioni tokovi između upravljačkih i upravljanih 
delova sistema, bez kojih nema upravljanja.

Upravljanje kretanjem organizovanih kolona nije ni teorijski dovoljno izučeno, nisu propisane nadležnosti i obaveze upravnih saobraćajnih organa i nije razvijena oprema za primenu savremenih metoda, modela i tehnika upravljanja. Funkcije upravljanja kolonama, osim planiranja, nerazvijene su, pa se i u literaturi često pod upravljanjem podrazumeva samo planiranje. Ono se objašnjava i razrađuje, a ostale funkcije su zanemarene.

Prema iznetom, efikasnost je važan pokazatelj za sve kolone, jedinice i nivoe komandovanja, pa svi subjekti treba da joj posvete odgovarajuću pažnju. Na ovaj način može se sprečiti nepotrebno trošenje resursa (puta, vremena i energije) i nepotrebni materijalni troškovi, uz po- boljšanje ekologije i bezbednosti saobraćaja.

\section{Literatura:}

[1] Gordić, S. R.: Efikasnost organizovanog vojnog kolonskog saobraćajnog toka, doktorska disertacija, Vojna akademija, Škola nacionalne odbrane, Beograd, 2005.

[2] Vujaklija, M.: Leksikon stranih reči i izraza, III dopunjeno izdanje, Prosveta, Beograd, 1980.

[3] Kukoleča, M. S.: Organizaciono-poslovni leksikon izraza, pojmova i metoda, Rad, Beograd, 1986.

[4] Ekonomska enciklopedija, drugo izdanje, Savremena administracija, Beograd, 1986.

[5] Opća enciklopedija Jugoslovenskog leksikografskog Zavoda, Zagreb, 1977.

[6] Marjanović, S.: Principi i instrukcije za rešavanje organizacionih problema, knjiga II, Privreda publik, Beograd, 1987.

[7] Krstić, V.: Povećanje efikasnosti ratne mornarice kroz tehničku modernizaciju u procesu opremanja novim i modifikacijama postojećih borbenih sistema i sredstava, ispitna tema za čin general-majora, 1987.

[8] Gordić, S. R.: Analiza kretanja organizovanog kolonskog saobraćajnog toka i kriterijuma njegove efikasnosti, magistarski rad, TVA KoV, Zagreb, 1983.

[9] Vrhovski, M.: Kvantitativna analiza parametara efektivnosti vozila u eksploataciji, VTG, 4, 1989.

[10] Priručni rečnik udruženog rada, IRO Ekonomika, Beograd, 1982.

[11] Miladinović, V.: Utvrđivanje borbene mogućnosti jedinica na bazi raspoloživih količina MTS iz nadležnosti SbSl, Bilten SbSl, br. 9, 1981.

[12] Pravilo o kontroli i ocenjivanju borbene gotovosti u Vojsci Jugoslavije, GŠ VJ, pov. br. 685-1 od 23. 10. 1997. 


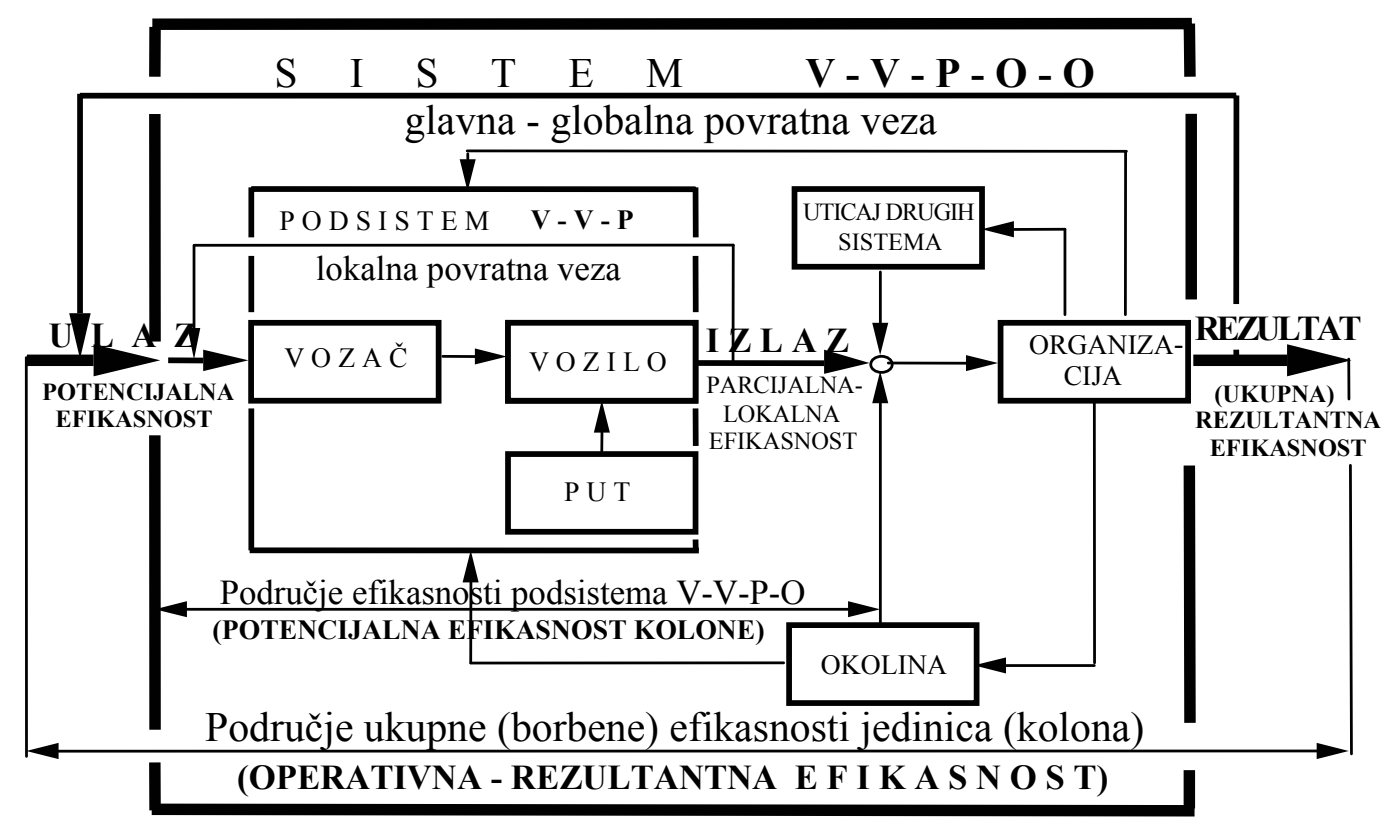

Sl. 1 - Klasifikacija efikasnosti u sistemu $V-V-P-O-O$ 

